\title{
Astrid Lindgren and the Archives
}

\author{
Helene Ehriander
}

\section{Linnæus University, Växjö, Sweden}

The author Astrid Lindgren (1907-2002), well-known for the characters Pippi Longstocking, the Brothers Lionheart, Emil and Karlsson-on-the roof, is for many Swedes a genuine national icon. On several occasions, when a list of the most popular and influential Swede has been published, Astrid Lindgren's name has been prominent. Around the year 2000 many Swedes voted Astrid Lindgren the most important person of the entire 2000 years, something that says much about our often short memory, but more about how popular Astrid Lindgren really is. In the year she turned 90 she was selected as 'This Year's Swede in the World' by The Society for Swedes in the World because few Swedes have been so esteemed throughout the world. On receiving the prize she said, 'You are giving the prize of This Year's Swede in the World to a person who is extremely old, half blind, half deaf and completely mad. We must be careful about spreading this around' (Törnqvist-Verschuur 2011, p.120).

Astrid Lindgren is known to Swedes not only as a famous author, but also as a person who spoke out on things she believed to be wrong in Swedish society, like the tax system and the lack of laws regarding animal welfare. In the history of Swedish literature 1945 is usually regarded as a milestone as this is the year Astrid Lindgren's book Pippi Longstocking was published, revolutionising both children's literature and the attitude to children and their upbringing. Astrid Lindgren also worked as editor-in-chief for the publishing house Rabén \& Sjögren from 1946 to 1970 and for almost a quarter of a century she was responsible for the publication of children's literature while at the same time being in practice her own editor. Today, ten years after she passed away at the age of 94, her remaining papers, letters and manuscripts are kept in different archives where interesting research can be carried out. There is a substantial amount of material from her rich and prolific life and in this article I wish to illustrate how this material can be used to provide a deeper knowledge of Astrid Lindgren as a person and as an editor.

\section{Astrid Lindgren at the Folk Life Archives}

What has made people love Astrid Lindgren so much that she remains a national icon to this day? What do we know about Astrid Lindgren and her work among the Swedish people, and what is it that we Swedes appreciate so much about this work? To try and answer some of these questions I 
compiled a questionnaire, which was distributed by the Folk Life Archives at the Division of Ethnology at Lund University in the autumn of 2009. The questionnaire, LUF 229, was sent to 130 informants all over the country. The informants are all volunteers who have agreed to answer questionnaires on different topics several times every year. The topics can vary but most often the questions are about subjects that traditionally fall into the categories of Folk Life studies or Ethnology. Examples of these subjects are wedding customs, funeral rites and attitudes toward personal hygiene. My questionnaire was also distributed by the Nordic Museum to their 150 informants in the spring of 2010.

These types of questionnaires have a very long tradition in Sweden. The concept was created in the beginning of the $20^{\text {th }}$ Century at Swedish Museums and Archives. In the beginning the purpose of these questionnaires was to examine and preserve traditions and customs that were disappearing: 'Save as much as you can for the future!' The Folk Life Archives in Lund was founded in 1913 by Professor Carl Wilhelm von Sydow, father of the famous actor Max von Sydow, and is the oldest archive in Sweden that collects information in this way. It is also the only folk life archive that is connected to an academic department, the Division of Ethnology at Lund University. Originally, the goal of the archives was to find local and regional patterns among the information collected, but today every informant represents her- or himself, and the interest in patterns and discernable structures has been disregarded. The questions in LUF 229 are divided into three sections concerning first Astrid Lindgren's books, then Astrid Lindgren's stories in other media and thirdly Astrid Lindgren as a person. These questionnaires were prepared with my various purposes in mind. I wished to collect material on Astrid Lindgren as an icon, and I intended, in a way consistent with the original idea of these questionnaires, to collect material of value for future researchers who would be able to see the answers in a historical light and be able to combine them with new questionnaires on books and reading.

The first paragraphs in the answers to the questionnaires are often a declaration of intent and the final paragraphs often include a short summary of what the informant has written about in his/her answer. When trying to analyse why Astrid Lindgren has become such a national icon, I was interested in studying the kind of values that are connected with her. Not surprisingly, all of the informants were genuinely fond of Astrid Lindgren and wrote a great deal about all the positive things connected with her, both as a person and as an author. There is nothing in all the answers I have received that can be interpreted negatively in any way. All of the informants are quite willing to share their admiration for Astrid Lindgren and they talk at length about how significant her books have been for them throughout their lives. Even those who do not really know anything about her or her books, who have not read anything by Lindgren, still try to say something positive about her. One woman born in 1923 who has not read a single book by Lindgren tried to contribute to the positive image of Astrid Lindgren: 'I don't think that I have much to add when it comes to Astrid Lindgren, but I want to give you an answer anyway: What a wonderful person!' 
Most of the informants began answering the first question of the questionnaire by remembering what they read as children. They also discussed their relationship to literature and they talked about the different ways in which Astrid Lindgren has been important:

'Astrid Lindgren is in all of our hearts' (Woman b.1953). 'Few Swedish writers are as loved as Astrid Lindgren' (Woman b.1939). 'Dear Astrid! Imagine that I could write as well as you, have the same incredible imagination, always renewing myself. I will never be as talented as you, however hard I try, but even if one is only half as talented as you, that is good enough' (Man b.1936). 'I am happy to be living in a country where children's literature is regarded so highly' (Woman b.1945). Astrid Lindgren is often called by her first name and this is, I think, because to many she is like a family member. A lot of people feel as if they have a personal connection with her, even if they have never met her: 'Astrid Lindgren feels like a good friend, even if I have never met her' (Woman b.1935). One of the respondents said:

She became so old and she was this great personality, I would say that I 'knew' her even better than I knew my own grandmother. When I see pictures [of her] I don't have a special emotional response, but when I hear her voice, well, then I really feel something, security, something so familiar, almost like someone you knew [...] She probably became so popular because she wrote such good books, because she was brave and tough and was never afraid to voice her opinions. And [she was] someone who retained a simple lifestyle even when she became quite wealthy (people like that because then they don't have to be jealous).

(Woman b. 1947)

On the whole, the answers to my questionnaire give us an image of a person with a kind heart and a generous personality and of a person who has not been swept away by her own success. Even if there were countless opportunities for Astrid Lindgren to be celebrated, to be wined and dined, to surround herself with luxuries and celebrities, she chose a private life. She preferred spending her time sitting on a porch in the archipelago to partying with royalty and enjoying free drinks. She was also very private about her personal life and in most articles published in connection with various anniversaries she usually said the same things, and was always very frugal with details. Even when the interviewing journalist tried to corner her with clever questions, he or she was often outmaneuvered and outwitted by Astrid Lindgren who steered the conversation to another subject, without risking her integrity. She seemed to be always kind, thoughtful, a good listener and empathic - but few really knew her. Astrid Lindgren managed to unite her need for privacy and integrity with forethought, humour, kindness and warmth in such a way that no one regarded her as inaccessible, uncommunicative or as having a big ego. She had the ability to shift the focus from herself to others, whether it was a colleague, a fan, someone in need or a journalist. And everyone felt her sincere interest and benevolence.

Several of the informants wrote about Lindgren's ability to handle media and her own fame, and said that she chose to be an ordinary person:

I got the impression that she was very private; maybe even a little cold to the media - a strategy that I always found to be honourable. That she lived a simple life, without to much fuss. How do I know this? Don't know. She succeeded in being in the public eye just as much 
as she wanted, which wasn't a lot [...] On the whole I have the impression that she managed her "celebrity" very well - she only spoke now and then and when she did, you really listened [...] This selective way of being in the public eye is something I think people feel a lot of sympathy for. She was quite ordinary and she only spoke when she had something to say.

(Man b.1963)

I think Astrid Lindgren was loved because she was human. She never became a bully or haughty or filled with self-importance. I think that Astrid Lindgren was kind, in the nicest sense of the word. This didn't stop her speaking out when she thought that something was wrong in our society. I have a deep respect for Astrid Lindgren as a person, and of course, as a writer. I have a few CDs that she recorded, reading Emil in Lönneberga, Samuel August from Sevedstorp and Hanna in Hult and a few other stories. I enjoy listening to her voice. I see her in front of me. I think she looks so sly sometimes.

(Woman b. 1932)

Some informants had met or seen Astrid Lindgren and they all describe this as a great occasion:

I have actually met Astrid Lindgren once. I was visiting an aunt who lived on Dalagatan in Stockholm. The elderly ladies were neighbours and helped each other with walks and doing the shopping. Astrid Lindgren was a lovely lady, just as one would have imagined a great storyteller.

(Woman b. 1949)

This quote is typical as it illustrates both how special Astrid Lindgren was as an author and how she was perceived as a person.

\section{The Memory of the World Register}

The period after the Second World War is known in Sweden as "the golden age of Swedish children's literature" since several of the great authors of children's and youth literature made their debuts and then continued to write for many years. A relatively stable group comprising Astrid Lindgren, Lennart Hellsing and Tove Jansson provided a solid base and they and many of their most notable colleagues were published by Rabén \& Sjögren. The house was, at that time, a relative newcomer to publishing. The business started in 1942 and very quickly established a profile as a publisher of quality books for children and young people. Certainly a major factor in the establishment of the company's reputation was the twin role of Astrid Lindgren as she was not only the editor of children's books but also the most important author for that company.

Astrid Lindgren worked as editor-in-chief for Rabén \& Sjögren from 1946 to 1970 and was responsible for children's literature for almost a quarter of a century. When she was appointed editor-in-chief Astrid Lindgren was already well known as an author; her first Pippi Longstocking book was published in 1945. She was also a qualified secretary and was regarded as extremely suitable to assist the company manager, Hans Rabén. The company believed that it was an opportune time to invest in children's and youth literature. Hans Rabén's involvement in children's and youth books led to his being internationally acknowledged; for instance, he was elected 
president of the International Board on Books for Young People in 1956 (Åkerman 1992, p.16). Marianne Eriksson, Astrid Lindgren's colleague and successor as editor, noted Astrid Lindgren's interest in tackling the publishing of children's books at the company: 'It was an exciting challenge, it sounded fun and she also needed the money!' Eriksson went on: 'Anyway, in the autumn of 1946 Astrid became responsible for children's literature at Rabén \& Sjögren. "I knew absolutely nothing about publishing", said Astrid herself, "but I knew a good book when I saw it. Or rather I should say, read it. It was simply to get going, searching for children's books."'(Eriksson 2001, p. 80). When Astrid Lindgren started her work at Rabén \& Sjögren she had the valuable experience of being on 'the other side', the author's, and therefore had a unique insight.

When it came to attracting new writing talent to Rabén \& Sjögren Astrid Lindgren soon became an invaluable resource. One cannot ignore her own experiences as a writer as well as her commitment and opinions about children's literature when one looks at the Swedish 'golden age of children's literature'. One way for the publisher to come into contact with new talent was the recurring competitions where Astrid Lindgren participated in formulating the rules, was a member of the panel of judges and took great responsibility for the competitions. That Astrid Lindgren was skilful as an author is common knowledge, but few know anything about the huge contribution that she made as an editor and even fewer can imagine how her advice and comments have shaped the writing of classic Swedish children's books for at least 25 years.

It is very interesting to see how Astrid Lindgren helped and guided a succession of her author colleagues in different ways. By studying the letters that have been preserved it is possible to construct a clear picture of how Astrid Lindgren worked and about her perception of what makes a good children's book. To sit on two chairs at the same time was never a problem for her. When she acquired her position at Rabén \& Sjögren there were many who believed that her own books might take priority, but the opposite occurred: 'She often went into the head of advertising and asked him not to make such a fuss of her.' (Carlberg 1992, p.29). In addition, Astrid Lindgren was determined to achieve the goal that as many children as possible should have access to as much good literature as possible.

Altogether there remain about 350 letters that bear witness as to how Astrid Lindgren worked as a publishing editor (Lindgren's relatives have given me permission to use the letters that were written to Astrid Lindgren and by her in her role as publishing editor). This number can be regarded as very low considering that for twenty-five years Astrid Lindgren typed many letters each day and had contact with both Swedish and foreign authors, but the small number of letters is also as a sign of how transient a letter can be. We should perhaps be grateful for the material that has been preserved, instead of complaining over all that has been lost. Many of these letters are privately owned since Astrid Lindgren chose to clear her office and throw all her papers out when she left the company, and few letters have been kept by the publishing house. Rabén \& Sjögren do not have a dedicated letters archive, but it has been possible to find a small collection of letters within the company. Astrid Lindgren rarely made copies of her letters, but authors as well as Astrid Lindgren's own relatives have saved some letters. A handful of letters are preserved at the 
university library in Lund and a complete collection of 130 letters over 30 years between the FinnoSwedish author Kai Söderhjelm and Astrid Lindgren are at Åbo Akademi in Finland. In addition there is correspondence with authors and illustrators in the Swedish Royal Library's handwriting collection - 'Astrid Lindgren Archives' - that occupies 150 metres of shelves; one of the largest collections left by any individual Swede. In 2005 this archive was included as part of UNESCO's 'Memory of the World Register', proof of how influential and important Astrid Lindgren was even abroad.

The 'Astrid Lindgren Archives' at the Royal Library was begun in 1980 when Astrid Lindgren herself donated part of her private archives to the handwriting department and has since then been complemented with material from Astrid Lindgren's home, from the Lindgren family and from other private contributors. The letters comprise for the most part fan mail from all over the world, often including children's drawings. A smaller component consists of correspondence with foreign publishers, Swedish writers, friends and family. The collection also includes the manuscripts of Astrid Lindgren's own books, plays, radioplays, film manuscripts, plus over 100000 press cuttings, accounts and 650 shorthand pads, and photographs, illustrations and Astrid Lindgren's own private library. The material covers almost 80 years and after Lindgren's death letters and books of condolence were added to the collection. Librarian Lena Törnqvist has commendably organised and cataloged a large part of the material so that it is today relatively easy to access (with the exception of letters, shorthand and delicate material). The shorthand is extremely difficult to decipher, even for experienced shorthand writers and it has required the expertise of parliamentary shorthand writers to sort and label each of the pads. In these pads are drafts of speeches and letters, parts of scripts, thoughts, notes from telephone conversations and diary notes. Many of the fan letters to Astrid Lindgren show 'the joy and experience of reading which she bestowed upon her readers from all walks of life and social background. There are letters from professors of literature, clergymen, bus drivers, politicians, company directors, teachers and housewives. Many of the letters are deeply personal. People had absolute trust in Astrid Lindgren and they often literally lay their lives in her hands. That is why the collection of letters 'will not be available in the foreseeable future', Lena Törnqvist writes in her article 'Från vindslåda till världsminne. Astrid Lindgrens arkiv i Kungl. Biblioteket' ('From the box in the attic to World Memory', undated, p.47).

\section{Hand Written Papers, Press Cuttings and Journals}

In university libraries there are large collections of press cuttings, newspapers and older journals. In Adam Helm's archives, stored at Stockholm University Library, there is a large collection of press cuttings where Astrid Lindgren is often mentioned in her role as both an author and an editor. Adam Helms (1904-1980) was a successful Swedish publicist at Bonniers, Sweden's largest ever publishing company. He worked at the same period as Astrid Lindgren but was primarily involved with adult literature and amongst other things introduced Ernest Hemingway to Swedish readers. After his death Adam Helms left a considerable collection of books and articles on the book market, publishing and on bookshops. 
In order to understand the background to Astrid Lindgren's position between her own authorship and the manuscripts sent by others, it is fruitful to study the view of books that she promoted as an editor, and the different archives provide various types of material here. As a publishing editor, Astrid Lindgren wrote sales letters to bookshops in a clever and well-informed way she informed them about the company's publications and attempted to encourage readership. In these letters, she wrote as an introduction: 'Astrid Lindgren calling'. This is something that naturally would have awakened the readers' interest. In these letters she paid most attention to the works of her author colleagues, even if her own books were mentioned.

A typewritten text preserved at The Swedish Royal Library explains the importance of Astrid Lindgren's concept of reading. She was herself a great reader, read books for both adults and children in several languages, and has testified in a number of contexts how important reading was to her throughout her entire life. It was important for her to explain this to others, especially to children. I have been unable to identify where this text was published, but it is possible that it was part of the company's sales material in the form of a letter to accompany a new publication where it is aimed directly to the child reader seeking both to challenge and also to persuade:

Which kind are you?

Here! Here is a book. Are you happy? Yes, books are something to be happy about. And learning to read is fun. It is even more fun when you can read and know that the world is full of books that are a complete joy to read.

There are two types of people. Some love to read while others never even look at a book if they can avoid it. Which kind are you?

If only you knew how lucky you would be if you became one of the first kind! How wonderful never to sit and be bored and sigh: What shall I do? You know that all you need to do is open a book, and you will immediately be in an enchanted world where anything at all can happen. Such that you can laugh at, cry with and even be made to shudder.

And do you know what? People who read lead a much better life than people who don't. That's how it is. It is also the case that many children learn how to read with pleasure. But then it is as if they lose the desire, and they simply don't want to read anymore. It must be because they don't find anything attractive in reading books.

But we who have made this book, we have really tried to make it as exciting and as varied as we could. Just so that you don't lose interest. Don't do it, then!

(acc 2009/28)

There are a few texts where Astrid Lindgren has written about children's literature and children's reading. These articles are reprinted in books on Astrid Lindgren, but the original articles are to be found in the paper archives at the university libraries. In these articles, written for a knowledgeable public with an interest in literature, Astrid Lindgren wrote about children's literature and her views on it. The first article is from the newspaper Svenska Dagbladet in 1953 under the headline 'Writing for children'. There we can see how Astrid Lindgren, several years before theorists began to talk about reader-response, emphasised the child's role as co-creator of a work of literature. She 
describes reading in a way that came to be known in theory as hermeneutics, an attempt to understand the reader's contact with the text and the author:

The writer should not boast too much. It is not to his credit that his words and sentences have a shimmering life which can summon bliss. It is the reader who has created the miracle. In the child, and only within the child, is an eternal, enviable fantasy that can create a fairytale castle if one only provides a pair of rough stones to build with. Everything mystical that is hidden between the covers of a book is created by the author and the reader together.

(Lindgren 1953)

In the same article Astrid Lindgren reflects on a quotation from the creator of Mary Poppins, Pamela Travers, who is reputed to have said: 'I write for the child within me' and intuitively Astrid Lindgren feels that she is right: 'One writes to entertain and satisfy the child that one once was.' The second article, 'Why children need books', was written in 1958 and published in Skolbiblioteket (School Library). In content it is similar to the first article, but here Astrid Lindgren goes a step further when she describes how children create miracles when they read. From taking the point of view that children co-operate by filling in 'the gaps' she now is convinced that there is a process and a dialogue going on between the text and the reader. This is similar to later research by Wolfgang Iser where he describes the process of reading, the subsequent development of the text into a unified work, and how the dialogue between the reader and text takes place. Astrid Lindgren placed great faith in the power of books and developed opinions about the ability of fantasy to change reality:

Books need a child's fantasy, that is true. But it is truer that a child's fantasy needs books to be able to live and thrive. There is nothing that can replace the book as fertile ground for fantasy. [- - ] A child alone with a book creates pictures somewhere in the secret rooms of the soul that are superior to everything else. Such pictures are necessary for human beings. The day that a child's fantasy can no longer create them is the day that the human race steps into poverty. All the great things that have ever occurred, happened first in someone's fantasy and how the world of tomorrow will be depends to a large degree on the power of the imagination that exists with those who are just about to learn how to read. That is why children need books.

(Lindgren 1958)

'A short conversation with an aspiring author of children's books' was published for the first time in Barn och kultur (Children and Culture) in 1970, but has since then been reprinted and quoted in several places. Here, Astrid Lindgren uses humour as the main weapon when she pokes fun at inferior children's literature as well as at authors who do not ask themselves questions about what a good book for children should be like. Astrid Lindgren herself answers that she has arrived at a notion of what a good children's book should be: 'It should be good. I can assure you that I have mused about it for a long time, but I can't find any other answer: It should be good.' She also compares the working conditions for authors of children's literature with those of writers of books for adults. She maintains that the same freedom should apply to all authors regardless of the age of their intended readers: 'Write freely and from the heart! I wish you and all authors of children's 
literature the freedom that a writer for adults obviously has, to write what he likes and how he likes.'

The article does not express support for a distinct ideology, apart from the importance of the harmony of content and language, Astrid Lindgren merely emphasises the right to freedom of expression for the authors of children's literature (Wallinder 1987, p.37). If it is not an ideology it is in any case a viewpoint that must have characterised her work as a publishing editor. The starting point for her reasoning in the article is clearly based upon the experiences that Astrid Lindgren accumulated during her time as publishing editor. Even if Astrid Lindgren does not touch upon her own authorship in the article, her double role is not uninteresting here. By asserting the artistic and literary value of children's literature, placing it alongside adult literature and demanding the same treatment and appraisal, she contributes to raising the status of children's literature and therefore indirectly her own position as an artist.

Astrid Lindgren was one of the first in Sweden to demand that the quality of a children's book should be the same as that of a book for adults and demand the same conditions for authors of children's literature as for writers of books for adults, irrespective of her role in this. Her view has conditioned attitudes towards children and children's literature on several levels as well as contributed to the development of a serious and literary approach to books for children.

\section{Astrid Lindgren as an Editor}

Astrid Lindgren was a considerate, honest and professional editor who always had the child reader's interests at heart. She often typed long letters giving detailed instructions on how a manuscript could be improved and explained, with care, what the flaws and weaknesses were. She had an eye for text and the capability to voice what she intuitively felt. She was focused and clearly explained her reasons for recommending changes in authors' manuscripts. Almost all authors have thanked her for the help that she has given them even if they, at the beginning, felt hurt that their submission was not as good as they thought when submitting it. In a letter from $5^{\text {th }}$ August 1970 Antoinette Baker voices the feelings of many of her fellow authors:

Dear Astrid,

Many thanks for your long kind letter! It is really extremely kind of you to be willing to help me and give of both your time and energy. Yes, I was a little taken aback for a day or two, especially when I realised how right you were, but now I am already delightfully upside down in the first chapter, and abstract expressions and confused phrases are discarded left and right.

And your point about not giving necessary information in the awkward dialogues really made me happy. I had myself been dissatisfied with precisely these sentences but did not know why. Thank you! If I now manage to write clearly and naturally for 5 - 7 year olds I do not yet know, but I will certainly try.

Astrid Lindgren was a witty and humorous person. A sense of fun is a necessary characteristic for a good children's book editor, and it is something that continually leaps from the pages of the letters 
that have been preserved. In a letter dated $30^{\text {th }}$ March 1966, Astrid Lindgren writes to a woman who has submitted a story written by her husband. Astrid Lindgren has considered the story and replies with a glint in her eye:

I have looked at your husband's fairytale for intelligent children and it is very skillfully done, but I think that it is more for the intelligent than for children. I don't think we have the possibility to publish the story.

With hearty greetings

Astrid Lindgren

When there was nothing else to do but reject a manuscript, Astrid Lindgren had the skill of doing so in a direct but friendly way, such as in a letter of the $9^{\text {th }}$ of March 1966:

We have read your jungle stories, but unfortunately we have no possibility to publish them in book form. The genre of speaking animals is rather over-exposed. We think it is difficult to create something fresh out of it. But we understand that the $H^{* * *}$ children must have a wonderful time experiencing these adventures in the jungle together with their father.

With friendly greetings

Astrid Lindgren

When it comes to manuscripts that have the potential to become good books, on the other hand, Astrid Lindgren exerts a great deal of effort to formulate what could be improved.

On $28^{\text {th }}$ July 1968 Astrid Lindgren is writing to the young writer Åsa Nelvin who has submitted a manuscript to the publishers. She writes a long letter to the aspiring author and this letter is privately held. After the encouraging introduction she goes through the manuscript pointing out the weaknesses, suggests improvements and motivates these in detail. Åsa Nelvin made the suggested changes and the book was published in 1969.

Dear Asa Nelvin, who one day will be a great story-teller, you have had to wait for the reply to your manuscript, and this is only because we were so many who have read and pondered and followed you on your visionary hike to The White Bears country - and such things take time.

It was indeed in many ways a strange manuscript, in parts distressing, in parts beautiful, and I don't doubt that you will, one day, be an author - in one field or an another, perhaps you will write for adults, perhaps poetry, there is much to indicate this. But now I must try to explain to you why The White Bears cannot be printed in its present form and why it is to your advantage that it isn't. [- - -] Your manuscript will be returned to you - save it as if it was a valuable treasure, so that you in your distant twilight years can read a lot about seventeen year old Asa Nelvin. Although, I would far rather that you grappled with it once more. It may perhaps not result in a book, but it would be good practise for Asa on her way to becoming an author.

With heartfelt greetings,

Astrid Lindgren 
That an author is not an isolated genius working in a vacuum is demonstrated by Astrid Lindgren and the Finno-Swedish author Kai Söderhjelm in letters conveying views on freedom. Astrid Lindgren advocates freedom for authors of children's literature, but it is a modified freedom. In these letters Kai Söderhjelm has to consider Astrid Lindgren's notions about what is commercially viable, what children can possibly appreciate, undefined 'general orders from above', the views of librarians and teachers about what is suitable for children, etc. Freedom is, in other words an illusion. If one examines Astrid Lindgren's declaration of freedom in 'A short conversation with an aspiring author of children's books' one finds that the freedom that she 'wishes' [my italics] for authors of children's literature is the same that writers of books for adults have. The only conclusions that one can draw from this is that not even writers of books for adults can use their freedom fully and that for authors of children's books to have equal freedom is actually wishful thinking. Freedom is really just a fine word, the meaning of which is limited by miscellaneous values and financial constraints. Freedom within a defined framework is available to authors, regardless of their target readership, but there is still an important difference in the framework: 'I can imagine that an adult writer who wants to be exclusive and needs the book as a playground for his desires and anguish can, perhaps, completely ignore his readers. He can have his small, narrow readership anyway as there is always the view that there are souls that will understand him. But those who write for children and youth and refuse to think about the readers are actually writing for no-one at all.' (Lindgren 1955)

The finances of the company are touched upon in several places in the correspondence and it is clear that Astrid Lindgren was forced to think in financial terms. Her knowledge about the book market and her experience as an author plays a role when she balances the artistic element with financial considerations about the company's output. In her role as a publishing editor, she is obliged to consider the reality of market forces. She writes that the income from the Enid Blyton books finances quality publishing and that she can't 'work to any other principle than to recommend books for publishing that according to my own conviction, whatever that now is, are appropriate for the readership for which they are intended'. The meaning of 'appropriate' is a question of interpretation, but it is interesting to observe that it is Astrid Lindgren's own conviction that governs what is published by Rabén \& Sjögren. Astrid Lindgren turns against trends and encourages writers to find their own styles. This is also true of her own authorship, for example is The Brothers Lionheart (1973), a genre cross-over tale with facets of both sagas and fantasy, published during the height of the social realism-trend in literature.

Astrid Lindgren's position as a national icon and Sweden's leading author of children's literature combined with her duties as publishing editor for the largest publisher of children's books is unique and of great interest. She was genuinely skilful, diplomatic and humble in relation to the authors, who in fact were also her colleagues. In his memoirs, Hellre kärlek än krig (Rather Love than War), Kai Söderhjelm has confirmed the importance of Astrid Lindgren for him personally and for Swedish children's literature as a whole over the years: 
For more than twenty years, she advised and guided me, took care of my books and was a constant support. I have perhaps already said many times that her great contribution as an editor should not be forgotten simply because she has had even greater success as an author. It is she who has made Swedish children's literature into an important and well-known branch of literature.

(Söderhjelm 1991, p.195)

An interesting thought is that Astrid Lindgren, despite her pronouncements against fashions and fads, was herself a trendsetter both as an author and as a leader of opinion. Her personality, values and opinions were valued qualities not only in her work at Rabén \& Sjögren but also in the Swedish society where she fought for the deprived, for children and for animals - for those who had no possibility of speaking for themselves.

\section{Acknowledgements}

Helene Ehriander has received funds from Riksbankens Jubileumsfond for research into Astrid Lindgren's role as publishing editor.

\section{References}

Åkerman, P. (1992) ‘Bokförläggaren Hans Rabén' ('Publicist Hans Rabén'), in K. Bohlund, P. Frank, J. Lagerstedt \& G. Rönnberg (eds) Rabén, Sjögren och alla vi andra. Femtio års förlagshistoria. Stockholm, Rabén \& Sjögren, pp.15-17.

Carlberg, G. (1992) 'God dag min välgörare!' ('Good Morning my Benefactor!’), in K. Bohlund, P. Frank, J. Lagerstedt \& G. Rönnberg (eds) Rabén, Sjögren och alla vi andra. Femtio års förlagshistoria. Stockholm, Rabén \& Sjögren, pp.28-29.

Eriksson, M. (2001) 'En bra bok ska vara bra' ('A good book should be good'), in S. Hellsing, B. Westin, S. Öhman-Sundén \& A. Lindgren (eds) Allrakäraste Astrid. En vänbok till Astrid Lindgren. Stockholm, Rabén \& Sjögren, pp.78-95.

Lindgren, A. (1953) 'Att skriva för barn' ('Writing for children'), Svenska Dagbladet, 1953-11-14.

Lindgren, A. (1958) 'Därför behöver barnen böcker' ('Why children need books'), Skolbiblioteket 3.

Lindgren, A. (1970) 'Litet samtal med en blivande barnboksförfattare'('A short conversation with an aspiring author of children's books'), Barn och kultur 6.

Söderhjelm, K. (1991) Hellre kärlek än krig (Rather Love than War). Stockholm, Rabén \& Sjögren.

Törnqvist, L. 'Från vindslåda till världsminne. Astrid Lindgrens arkiv i Kungl. Biblioteket'. ('From box in the attic to world memory') Kungliga biblioteket. Available from:

http://www.kb.se/Dokument/Biblis/33_tornqvist.pdf_[accessed 14 august 2012]

Törnqvist-Verschuur, R. (2011) Den Astrid jag minns ('The Astrid I Remember'). Vimmerby, Astrid Lindgren-Sällskapet.

Wallinder, A. (1987) Vem bestämmer? ('Who decides?'). Gävle, Cikada. 


\section{Letters and unpublished material}

Letter from Astrid Lindgren to Kai Söderhjelm in June 1955, handwriting section of Åbo Akademi.

Letter from Astrid Lindgren, 9 March 1966, Rabén \& Sjögren’s archive.

Letter from Astrid Lindgren, 30 March 1966, Rabén \& Sjögren's archive.

Letter from Astrid Lindgren to Åsa Nelvin, 28 July 1968, private archive.

Letter to Astrid Lindgren from Antoinette Baker, 5 August 1970, Kungliga biblioteket (Swedish Royal Library).

Astrid Lindgren collection, Kungliga biblioteket (Swedish Royal Library), acc 2009/28.

LUF 229, Folk Life Archives at the Division of Ethnology at Lund University.

\section{SOCR}

\section{Biographical Note}

Helene Ehriander is a lecturer in the Department of Comparative Literature at the LinnæusUniversity of Kalmar/Växjö. She defended her thesis on 'Humanism and the View of History in Kai Söderhjelm's Historical Novels for Children and Young People', in Comparative Literature at the University of Lund in October 2003. She is currently writing a book on Astrid Lindgren as an editor at the publishing house Rabén \& Sjögren and completing a study on Astrid Lindgren as an Swedish icon. 